\title{
Women participation in Agriculture in Pakistan (An overview of the constraint and problems faced by rural women)
}

\author{
Dr.Rummana Zaheer*, Aniqa Zeb**, Sanam Wagma Khattak*** \\ Assistant Professor, Department of Economics, University of Karachi \\ Student, department of Economics, University of Karachi \\ Student, department of Economics, University of Karachi
}

\begin{abstract}
Agriculture is back-bone of the Pakistan's economy. A major part of the GDP comprises of that income which is generated by the agriculture and agro-base activities. Women are back-bone of the household economy and play a very significant role in agro-base activities in rural areas. This study consist of almost half of the population i.e. women- participation in agriculture. Data is taken from Pakistan and India in order to compare figures from both countries as both economies are similar in socio-economic cultures. Data is taken from1990 to 2012. This paper also covers the reasons of fluctuation in women employment in agriculture and measures which concerned authorities should adopt in order to increases not only participation but also productivity of female labor.
\end{abstract}

Key words: agriculture, education, economy, fluctuations, problems, productivity, significant

\section{Introduction:}

This topic is chosen to describe women are the majority of the population in Pakistan and they play a very significant role in every field of life. Agriculture is one of the most important sectors in the Pakistan economy. As agricultural activities are conducted in the rural areas of the country women play a pivotal part in agriculture and agro-base other activities.

The productive work done within the agriculture fields by women has been ignored and not much attempt has been made to incorporate the value of such activities within the national accounts. This is the main reason behind the exceptionally low female labor participation rate of $18.93 \%$ compared to $71.97 \%$ for men in Pakistan (GOP, 2007).

$79 \%$ of rural female population is engaged in agriculture as against $61 \%$ of rural male population.

This paper consists abstract of review of literature, data and analysis, comparison of contribution of women between Pakistan India; comparison is on the basis of female labor participation in agriculture. In the second last section conclusion of the study and recommendations and last section of the paper is references.

\section{Review of Literature:}

The female segment forms about 50 percent of the total population of the country, whereas its formal participation in economic activities is minimal (Pakistan Economic Survey: 2007-2008).

There is a widespread conception that compared to other regions in the world, women in WANA have a very marginal role in employment in all sectors of the economy including that of agriculture, and that they participate mostly in consumption and reproductive activities from within the boundaries of their household and under the dictatorship of male members of the family. Whether this conception is true, or whether women play more significant roles in the food production systems in WANA. (CGIAR Gender Program, working paper no.10)

(Tanzeel, Imran 2012) Female work more than male in farming but they do not get proper food and medical treatment and deprive from many basic necessities of life. Gender discrimination on the basis of socially constructed moralities and duties are very common in Pakistan. This study highlighted that the role of women in agricultural development is not limited and women's role in agriculture sector should be realized. There should be some laws for the protection of women's rights on prior level that could not be violated at any cost. Women farmers need to learn skills for improved agricultural operations and for better post harvest practices and storage.

(Razia Begum, Ghazala Yasmeen2011) Agriculture is major sector of not only Pakistan but of all developing and less developed countries and a large portion of the population of these countries is engaged in agriculture and agro based activities. Women, which are the almost half of the population are as important labor force of the agriculture sector as men but their importance is not recognized in our country as it should be. There constraints 
and obstacles like malnutrition, low education, migration, poor technical facilities, on the top gender issues which are not allowing a huge portion of female labor force to contribute according to their capabilities.

Prakash (2003) described that there are many constraints that discourage the women in development and thus major sex of the world cannot contribute their power in economic sector. There is patriarchal system that is existed in some societies which does not allow women to work with other male workers. There are also cultural barriers and religious interpretations that create hurdles in women social mobility. These factors are resulted the less women participation in agriculture sector. This portion of human being is generally invisible in development activities.

Zafar (2003): Pakistani women work simultaneously as mother, household laborers and social production workers, but still economic value of her contribution is undervalued. Furthermore, he criticized that in agriculture individual contributed equally to productivity but their efforts are rewarded on the basis of noneconomic criteria e.g. sex which raises serious questions of equity and human justice. Therefore, the development planning must be backed by developmental objectives instead of basing decisions on physical input and outputs which ignores the perspective of human resources, and the social dimensions of agriculture.

(Dr.Roshan Lal, Dr Ashok Khorana 2011): Rural women not only in Pakistan but in all developing countries face many constraints instead of working more and harder. These constraints are of many kinds i.e. social, economic, gender biasness, low education, lack of access to prior opportunities and facilities etc. They do all the agricultural work except plaguing besides household responsibilities, they are also efficient in agriculture allied fields but are being rewarded according to their efforts and devotion.

(W.H.M. Jaim and Mahbub Hossain2008): migration of male population due urbanization or for better work opportunities is a reason which could impact good in increasing female population in agriculture but on the other hand it also increases their responsibilities. It is important to facilitate female in all senses of agriculture i.e. making them familiar to the technology which enhance their productivity and reduces the pressure of burden.

(BUTT et al 2010): Rural women play a unique and major role in the food security. Different kinds of constraints hinder their way to give $100 \%$ potential in the agriculture production. Constraints are lack of access to credit and new and latest information about how to increase productivity, technology and some social constraints like male domonance, traditional belief system, resistence from family members etc.

\section{Data and analysis:}

Pakistan and India have same geographical environment, weather conditions and to some extent same norms and values. So, comparison of female labor force is good to draw some useful results;

\begin{tabular}{|l|r|l|r|}
\hline Table 1: & $\begin{array}{l}\text { Female } \\
\text { labor }\end{array}$ & Force of Pakistan & And India \\
\hline India & Years & $\begin{array}{l}\text { Total agriculture labour } \\
\text { force }\end{array}$ & Female labor force \\
\hline & 1990 & 210181 & 68098.64 \\
\hline & 2000 & 239959 & 77746.72 \\
\hline & 2010 & 269740 & 87395.76 \\
\hline & 2011 & 272706 & 88629.45 \\
\hline & & & 2452.172 \\
\hline Pakistan & & & 4285.048 \\
\hline & 1990 & 15044 & 7380.52 \\
\hline & 2000 & 18712 & 7681.754 \\
\hline
\end{tabular}

Source: Unctad Handbook of statistics 2012

This data comprises of 10 years statistics of female labor force of the two economies.

As India's population is larger than Pakistan's population so the female participation ratio is also greater. From 1990 to 2010 and 2011 female involvement in agricultural activities is increasing because of the steps taken by the Indian Agricultural concerned authorities. Another factor is migration of male to urban areas for batter sources of income which not only increased female contribution in agriculture but on the other way lengthen the existing responsibilities. 
Many projects were started by Govt. but also by NGOs for women empowerment which increases women's interest in agriculture and purify her intention for batter activities in agriculture. Farm training, self help groups, credit access and making familiar with new productive techniques these are the few measures or steps that are being taken to increase the female labor participation in agriculture.

Looking at the figures in Pakistan, there is also increasing trend in female labor force. A major reason is also migration of male labor force towards manufacturing industry for batter and permanent income sources. Women is Pakistani society have a very helping hand towards agricultural activities along with their household responsibilities. Mostly women are unpaid for the work and responsibilities she carries so her contribution is understated and even looked in the statistics.

Figure 1:\% of female employees

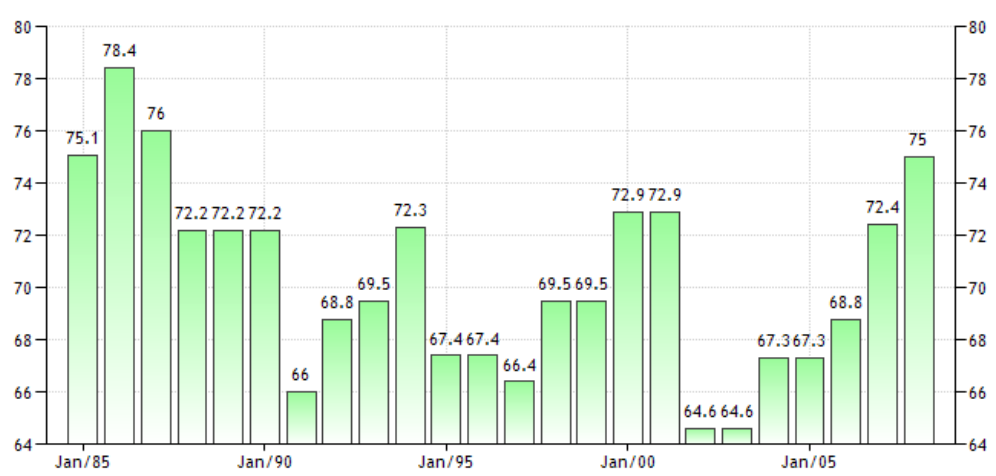

Source: World Bank Indicators: Pakistan - economic activity

Employees in agriculture, percentage of female were 75 in 2008 according to World Bank. It varies from year to year. Fluctuations occurs in employment but it is a healthy sign that women employment is increasing and soon it will be according to ratio as it should be. Because it is necessary to engage rural women to economic activity which they can perform as well as male.

\begin{tabular}{|c|c|c|c|c|c|c|c|}
\hline \multicolumn{8}{|l|}{ Persons in mlns } \\
\hline & \multicolumn{4}{|c|}{ 2001-02 } & \multicolumn{3}{|c|}{ 2003-04 } \\
\hline Major Industry Division & \multicolumn{2}{|c|}{ Rural } & \multicolumn{2}{|c|}{ Urban } & \multirow{2}{*}{$\frac{\text { Rural }}{\text { Male F }}$} & \multirow{2}{*}{\multicolumn{2}{|c|}{$\begin{array}{lc} & \text { Urban } \\
\text { Female } & \text { Male }\end{array}$}} \\
\hline Female & Male & Female & Male & Female & & & \\
\hline \multicolumn{8}{|c|}{ Agriculture, forestry hunting \& } \\
\hline $\begin{array}{l}\text { Fishing } \\
0.18\end{array}$ & 12.17 & 3.56 & 0.52 & 0.12 & 12.62 & 4.57 & 0.60 \\
\hline $\begin{array}{l}\text { Manufacturing } \\
0.42\end{array}$ & 1.84 & 0.47 & 2.67 & 0.39 & 1.97 & 0.62 & 2.73 \\
\hline $\begin{array}{l}\text { Construction } \\
0.00\end{array}$ & 1.65 & 0.01 & 0.69 & 0.00 & 1.71 & 0.01 & 0.71 \\
\hline $\begin{array}{l}\text { Wholesale and retail trade } \\
0.04\end{array}$ & 2.40 & 0.05 & 3.27 & 0.05 & 2.61 & 0.08 & 3.44 \\
\hline \multicolumn{8}{|l|}{ Transport, storage and } \\
\hline $\begin{array}{l}\text { Communication } \\
0.01\end{array}$ & 1.27 & 0.02 & 1.00 & 0.00 & 1.24 & 0.00 & 1.14 \\
\hline \multicolumn{8}{|c|}{ Community, personal and social } \\
\hline $\begin{array}{l}\text { Services } \\
0.69\end{array}$ & 2.61 & 0.35 & 2.42 & 0.64 & 2.54 & 0.43 & 2.61 \\
\hline $\begin{array}{l}\text { Others } \\
0.01\end{array}$ & 0.24 & 0.00 & 0.43 & 0.01 & 0.23 & 0.00 & 0.53 \\
\hline $\begin{array}{l}\text { Total } \\
1.35\end{array}$ & 22.18 & 4.47 & 11.01 & 1.22 & 22.93 & 5.71 & 11.76 \\
\hline
\end{tabular}

Source: Second Quarterly report FY05 
There is an evident decline in the unemployment rate, this gain is largely concentrated in rural areas, particularly in females, and is visible in higher number of unpaid family helper. This view is also supported by rising share of agriculture and allied industry in the distribution of female labor force by major industries.

\section{Conclusion:}

For the rapid and sustain development, it is need of the time to realize the importance of female in agriculture and give them reorganization which is lacking in their work and sacrifice.

Female labor force is as efficient as male population. They perform household duties which are considered as part of their life and inborn duty. These works consume a lot of efforts and time in their daily life but all this hardship is unrecognized. This is not enough for a rural women's life she is as active as a man in agriculture but also in agro-based activates. But instead of that much contribution in the economy she is dominated by male population, she is less paid; her hardships are under sated not only in the society but also in the statistics of the Government.

Women participation is understated most of the times which is not healthy for the state of economy because women are the majority of population especially in rural areas of the country where agricultural activities are conducted. Reorganization of resources in such a way that female also gets credit, access to the market and knowledge of work.

All works done by rural women - agriculture, livestock and traditional crafts making — should be recorded to ensure their access to resources, to open bank accounts and to borrow money and buy agriculture inputs like fertilizers and seeds. The government should offer agricultural subsidies to women farmers in order to utilize the immense and talented gender.

There is a need for revising agricultural policy and making reforms keeping insight women's problem in playing an important and significant role in economy. It should eliminate gender biasness, provide quality education, and give them latest technology which is the need of time to stand in the line with developed countries

Following recommendations Govt. should made to enhance and stabilize the female participation according to capacity and need of the development in agriculture sector:

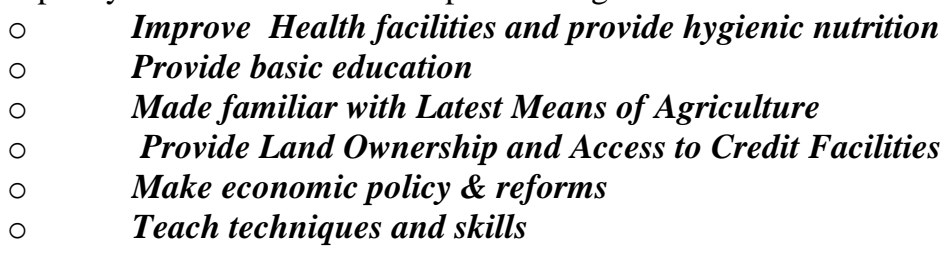

\section{References:}

[1] Butt et al "Role of rural women in agricultural development and their constraints". Journal of Agriculture Social sciences

[2] Dr. Roshan Lal, Dr. Ashok Khorana (2011) Gender Issues: "The role of women in agriculture sector".

[3] Economic Survey of Pakistan 2007-2008

[4] Irum Feryal, Imtiaz Ahmad Waraich, Imran Hanif, Tanzeel ul Rehman Alvi \& Naveed Mortaza "Women Participation in socioEconomic Development in Agriculture Areas in Pakistan"

[5] Manzoor Ali Isran, Samina Isran (2012) "Low female labor participation in Pakistan: Causes \& Consequences"

[6] Noreen Mujahid \& Naeem Uz Zafar: "Economic growth-Female labor Force Participation nexus:" "An empirical evidence for Pakistan"

[7] Razia Bygum, Ghazala Yasmeen (2011) “Contribution of Pakistani women in Agriculture: productivity and Constraints" Sarhad J. Agric. Vol.27, No.4, 2011

[8] "State of Pakistan's economy": Second Quarterly reportFY05

[8] Sustainable development Department SD, Food and Agriculture Organization of the United Nation"

[9] Unctad "Hand book of statistics 2012"

[10] W.H.M. Jaim \& Mahbub Hussain: "Women participation in agriculture in Bangladesh from 1988-2008" 